\title{
Konflik Palestina dan Israel: Perspektif Komunikasi
}

\author{
Junardi \\ ABSTRACT

\begin{abstract}
A harsh incident which killed Hamas top leader, Abdul Aziz Rantisi, has escalated Middle East conflict. As had been cited from many sources, Palestinians and Israelis publicly stated strong comments and blamed each other over this incident. From communication perspective, this incident and the aftermath became an example of labeling-based-conflict. Such conflict was resulted from ideological influence, life and everyday beliefs, and also religion background. One can prevent the incidents if only such differences could be maintained and managed wisely.
\end{abstract}

Kata kunci: intergroup labeling, konflik, Palestina, Israel

Petikan peristiwa di atas, memberikan gambaran bagaimana konflik komunikasi yang terjadi di Palestina, akibat adanya perbedaan ideologi, agama, dan pandangan hidup. Hal inilah yang akan diuraikan dalam tulisan ini.

Sebelum melihat konflik komunikasi tersebut. Ada baiknya disamakan dahulu persepsi mengenai arti dari komunikasi itu sendiri. Kata komunikasi atau communication dalam bahasa Inggris berasal dari kata Latin communico, communicare, yang berarti "membuat sama"(to make common). Istilah pertama (communis) adalah istilah yang paling sering disebut sebagai asal usul kata komunikasi, yang merupakan akar dari kata-kata Latin lainnya yang mirip. Komunikasi menyarankan bahwa suatu pikiran, suatu makan, atau suatu pesan dianut secara sama. Akan tetapi, definisi-definisi kontemporer menyarankan bahwa komunikasi merujuk pada cara berbagi hal-hal tersebut, seperti dalam kalimat "kita berbagi pikiran","kita mendiskusikan makna", dan "Kita mengirimkan pesan". ${ }^{2}$

Di Amerika Serikat, muncul communication science atau kadang-kadang dinamakan juga communicology, ilmu yang mempelajari gejalagejala sosial sebagai akibat dari proses komunikasi massa, komunikasi kelompok, dan komunikasi antarpersona. Kebutuhan orang-orang Amerika akan science of communication tampak sudah sejak tahun 1940-an, pada waktu seorang sarjana bernama Carl I. Hovland menampilkan definisinya mengenai ilmu komunikasi. Hovland mendefenisikan science of communication sebagai: "a systematic attempt to formuatate in rigorous fashion the principles by which in formation is transmitted and opinions and attitudes are formed. Upaya yang sistematis untuk merumuskan secara tegar asas-asas penyampaian informasi serta pembentukan pendapat dan sikap. ${ }^{3}$

\section{Etnosentrik}

Sejarah telah menunjukkan bahwa sebagian konflik dan peperangan antarbangsa disebabkan karena para pemimpin bangsa yang satu tidak memahami dan menghargai budaya bangsa lain. Mereka etnosentrik (merasa budaya bangsanya sendiri lebih baik daripada budaya bangsa lain) 
dan punya prasangka atau stereotif terhadap bangsa lain. Misalnya, Hitler dan pasukannya, melakukan invasi ke negara-negara lain di sekitarnya karena di samping alasan-alasan lain, ia pun percaya bahwa bangsa Jerman adalah bangsa paling mulia dan karena itu bangsa Jerman berhak menguasai negara-negara lain. Juga, Amerika mengebom Hiroshima dan Nagasaki pada zaman Perang Dunia II itu bukan saja karena Amerika ingin mengalahkan Jepang, tetapi seperti dikatakan Maryam Jamilah, juga karena saat itu (para pemimpin) bangsa Amerika sangat membenci bangsa Jepang.

Harus diakui bahwa dewasa ini masih terdapat bangsa-bangsa etnosentrik demikian. Contoh yang jelas adalah kaum kulit putih yang menindas kaum kulit hitam di Afrika Selatan dan bangsa Yahudi yang menindas bangsa Arab Palestina. Kedua bangsa itu merasa lebih mulia daripada bangsabangsa yang dikuasai.

Dalam taraf yang rendah, konflik antarbangsa merupakan kesalahpahaman antara individuindividu yang berlainan bangsa. Sumber konflik atau kesalahpahaman yang lazim terjadi ini antara lain adalah stereotif-stereotif antarbangsa. Kita pun, bahkan tanpa kita sadari, bisa jadi mempunyai stereotif-stereotif terhadap bangsa lain. Stereotifstereotif yang kita miliki tentang orang-orang Amerika, misalnya bahwa mereka itu menganut citra bebas, penganut seks bebas, materialistik, indivudualistik. $^{4}$

\section{"Labelling"}

Terjadi labelling pada konflik Palestina dan Israel, di mana kita mengenal labelling teroris, fundamentalis, dan Zio Nazism. Teori labelling ini diinspirasikan oleh teori interaksi simbolik George Herbert Mead dalam bukunya, Mind, Self, and Society (1934). Menurut teori Mead, orang belajar memainkan peran dan mengasumsikan identitas sedemikian relevan dengan peran-peran ini, yang menunjukkan satu sama lain siapa dan apa kedudukan mereka, yang mendefinisikan situasi-situasi yang mereka jumpai, dan terlibat dalam perilaku-perilaku yang berkaitan dengan identitas, makna, dan situasi sosial sedemikian. Teori Labelling berasumsi bahwa penyimpangan bukan seperangkat ciri individu atau kelompok, melainkan suatu proses interaksi antara para penyimpang dan bukan penyimpangan. ${ }^{5}$

Selain Labelling yang terjadi, di dalam konflik Palestina Israel juga terdapat komunikasi yang dibahasakan dengan senjata dan kekerasan. Artinya, komunikasi dapat berupa bentrokan dan saling bunuh diantara kedua pihak yang bertikai.

\section{Dinamika Konflik}

Dalam situasi perang dinamika konflik yang ada yaitu berupa tiga dimensi penting dalam konflik, yaitu:

(1) Konteks atau situasi perang

(2) Persepsi di antara pihak-pihak yang terlibat dalam konflik, baik pihak langsung maupun pihak tidak langsung

(3) Perilaku pihak-pihak berkonflik selama konflik berlangsung (Mitchell, 1981)

Ketiga dimensi tersebut saling berhubungan satu sama lain secara bersama-sama membentuk konflik. Konflik pada umumnya berawal ketika terjadinya perubahan-perubahan dalam realitas struktur dan kultur dalam masyarakat, sehingga menciptakan kesenjangan atau ketimpangan struktural-kultural yang mencolok. Situasi demikian mudah menciptakan persepsi saling curiga, tidak percaya, ketegangan, dan sikap permusuhan antarkelompok dan akhirnya nudah berubah menjadi perilaku konflik terbuka, bentrok, perang, dan kekerasan. Ketika perilaku konflik berlangsung, perang terjadi. Hal itu kembali akan mempengaruhi sikap permusuhan menjadi semakin intensif, khususnya jika perilaku konflik yang berlangsung telah menimbulkan kekerasan, kerusakan atau korban yang luas, baik di kalangan pihak-pihak yang berkonflik maupun kalangan yang luas, baik di kalangan pihak-pihak yang berkonflik maupun kalangan luas di arena konflik. ${ }^{6}$

Hal ini dapat kita lihat pada konflik Palestina Israel, dimana Amerika Serikat dan Inggris ikut campur dan mendukung Israel. Intervensi dari pihak lain ini menimbulkan semakin lebarnya konflik yang terjadi. Kemudian dikatakan pula Lambang 
Trijono, ketika konflik telah menjadi konflik kekerasan bersifat terbuka, maka ketersediaan informasi yang seimbang dan proporsional akan semakin langka dan menurun draktis. ${ }^{7}$ Maka komunikasi yang berlangsung antara pihak-pihak yang berperang juga mengalami krisis yang hebat. Jenis komunikasi yang ada dalam situasi yang demikian hanyalah komunikasi perang karena langkanya informasi yang seimbang dan proporsional tentang situasi, persepsi, dan perilaku konflik yang ada.

Pecahnya perang sipil antara etnis dan agama di Maluku, misalnya, merupakan contoh yang sempurna bagaimana langkanya informasi yang seimbang dan proporsional tentang situasi, persepsi, dan perilaku konflik serta memburukkan situasi konflik yang ada. Hal ini juga berbias dalam pemberitaan mengenai konflik yang terjadi di media massa. Kita dengan mudah dapat menemukan betapa tidak proporsionalnya liputan tentang konflik kekerasan dalam wacana konflik di berbagai media dewasa ini. Hal ini memang terjadi karena kecenderungan sangat terbatas dan langkanya ketersediaan informasi yang seimbang dan proporsional tentang konflik dalam situasi krisis, sehingga informasi yang ada mudah dimanipulasi oleh pihak-pihak yang berkonflik.

Situasi krisis atau perang umumnya ditandai oleh paling tidak empat karakteristik berikut ini:(1) Risiko kehilangan sesuatu atau kalah di mata pihak-pihak berkonflik begitu sangat tinggi; (2) sangat sedikit waktu yang tersedia untuk mengambil keputusan yang penting karena itu dipandang sangat perlu untuk segera mengambil keputusan; (3)informasi penting tentang konflik seringkali tidak tersedia, sehingga cenderung masuk dalam situasi ketidakpastian sangat tinggi tentang apa yang sedang terjadi dan bagamaimana mensikapinya; (4) terdapat semacam perasaan akan semakin sempit dan sedikitnya pilihan bisa diambil untuk mengatasi krisis(Ury \& Smoke 1985)

\section{Konflik dan Tingkatannya}

Untuk menjawab pertanyaan mengenai konflik dan mengetahui arti konflik itu sendiri. Smith dan Berg (1987, dalam Stewart L Tubbs \& dan Sylvia,
Moss, 2001) mendefinisikan konflik kelompok sebagai "pertentangan kekuatan-kekuatan yang berlawanan, yang meliputi gagasan, sumber daya, kepentingan, harapan atau motivasi"

\section{Tingkat Konflik}

Phillips (1988) mengidentifikasikan konflik dengan menawarkan suatu model bertingkat, yang berguna dalam mengidentifikasi berbagai tahap konflik yang meningkat:

Tingkat I: Perbedaan

Pada tingkat ini, tujuannya adalah menyelesaikan konflik. Ada pertukaran bebas informasi yang jujur. Suasana emosional merupakan harapan dan kepercayaan terhadap kemampuan kedua pihak untuk menyelesaikan perbedaan mereka.

Tingkat II:Perselisihan

Pada tingkat ini, tujuan berubah menjadi rugi sesedikit mungkin. Pertukaran informasi kini dijaga. Kedua pihak sering memperhitungkan kemungkinan peran mendadak. Suasana emosional menjadi kesopanan yang dipaksakan dan ketidaksabaran.

Tingkat III: Pernyataan

Kini tujuannya bukan lagi menemukan tingkat keuntungan atau kerugian yang disepakati bersama, melainkan untuk menang. Kedua pihak bertukar informasi bukan dengan tujuan untuk menyelesaikan masalah, melainkan untuk membuktikan sesuatu. Suasana emosional menekan. Perbincangan memanas, karena kedua pihak takut kalah. Pada tahap selanjutnya, kedua pihak frustasi dan menunjukkan kemarahan kepada pihak lawan dan kadang-kadang kepada mitranya.

Tingkat IV: Pertarungan Terbatas

Tujuannya sekarang adalah mengurangi kekuatan lawan sehingga lawan tersebut bukan suatu gangguan lagi. Kedua pihak mulai aktif mencari sekutu politis. Apa pun fakta yang semula dipermasalahkan menjadi benar-benar kabur. Pertarungan beralih pada pribadi masing-masing. Suasana emosional ditandai dengan sakit hati, kemarahan, dan rasa benci.

Tingkat V: Perang Sebenarnya 
Tujuannya adalah melenyapkan pihak lain dengan risiko apa pun. Kemenangan merupakan hal terpenting. Kedua pihak berusaha keras saling menghindari. Suasana emosional ditandai dengan pelecehan.(Phillips, 1988, hlm 66-71) ${ }^{9}$

Sementara itu, dalam melihat perilaku-perilaku konflik, banyak ahli teori yang mencoba membuat skema pola-pola respons terhadap konflik (Misalnya, Bach dan Deutsch, 1985; Sillars et al., 1982; Hocker dan Wilmot, 1991). Dalam beberapa hal, pola-pola ini bertumpang tindih; istilah-istilah berbeda kadang-kadang digunakan untuk menyebutkan perilaku yang sama. Sillars et al. (1982) dan Hocker dan Wilmot (1991) mengemukakan tiga kategori perilaku konflikpenghidaran, taktik kompetitif(atau mengganggu), dan taktik kolaboratif (atau integratif). ${ }^{10}$

\section{Rintangan Komunikasi}

Perbedaan ras adalah pengertian yang bersifat biologis. Ciri-ciri dari sesuatu ras terletak pada fisik yang dimiliki oleh ras tersebut, umpamanya warna kulit, bentuk rambut, hidung, bibir dan lain-lain. Secara konvensional, kita membedakan tiga macam ras, yaitu Mongoloid, kaukasoid, dan Negroid. Menurut Ilmu Antropologi dan Sosiologi, perbedaan-perbedaan dalam ciri-ciri fisik tersebut sama sekali tidak mempengaruhi kecakapan, kecerdasan, dan kecerdikan sesuatu ras. Daya cipta dan kemampuan menghasilkan karya-karya kebudayaan tidak ada sangkut pautnya dengan warna kulit. Namun kenyataan perbedaan ras tersebut menimbulkan rintangan-rintangan dalam proses komunikasi. Lihat bagaimana di Amerika, di Afrika dan di tanah-tanah jajahan dahulu. ${ }^{11}$

\section{Analisis Konflik Palestina vs Israel}

Yang menarik untuk dibahas komunikasi dari perspektif adalah konflik antara Palestina dan Israel yang telah berlangsung cukup lama. Untuk menggambarkan konflik antara kedua belah pihak ini, seperti yang terjadi pada pertemuan Forum Sosial Dunia (WSF) 2003 di Porto Alegre, Brazil, acara yang dikhususkan sebagai pengimbang Forum Ekonomi Dunia di Davos, sentimen anti Yahudi begitu kental.

Ekspresi anti Yahudi tak hanya didengungkan orang-orang Palestina atau Arab, tetapi juga oleh kaum ekstrem kanan seperti Neo-Nazi dan ekstrem kiri yang menuduh arsitektur sosial dan ekonomi dunia kini telah ditata sedemikian rupa sehingga hanya menguntungkan sekelompok kecil manusia di mana sumbu dan tubuhnya dihuni komunitas keturunan Yahudi. Di Porto Alegre ini, para demonstran mengusung spanduk-spanduk mengerikan. Puluhan ribu orang membentangkan spanduk "Nazi, Yankee (AS), dan Yahudi: Tidak ada Manusia Terpilih! Beberapa mengenakan kaus bergambarkan bendera Bintang Daud, lainnya swastika (lambang Nazi).

Orang-orang Palestina meneriakkan yel "Yahudi adalah fundamentalis sejati yang mengendalikan kapitalisme Amerika." Menurut Mark Strauss, editor jurnal Foreign Policy, sejak runtuhnya Tembok Berlin, prasangka rasial muncul lagi ke permukaan dan memuncak pada 2002 ketika gerakan anti-Yahudi mencapai tingkat paling provokatifnya selama 12 tahun terakhir. Kebencian lama itu menghebat luar biasa. Media-media Eropa menggambarkan kedengkian lama pembunuhan Yesus Kristus oleh pemuda Yahudi. Palang Merah Internasional dan Bulan Sabit Merah menolak Bintang Daud ditempelkan di ambulans-ambulans mereka. Zimbabwe dan Malaysia memeringatkan konspirasi Yahudi internasional yang tengah menguasai sistem keuangan dunia.

Para aktivitis Neo-Nazi membagi-bagikan buku karangan Adolf Hitler, Mein Kampf, kepada para pemuda Palestina. Sejarah seakan berulang. Hampir dalam setiap krisis ekonomi dunia, Yahudi yang memang mengontrol sistem keuangan, ekonomi dan kebijakan di banyak sistem politik selalu dipersalahkan. ${ }^{12}$

\section{Ciri-Ciri Masyarakat Israel}

Prof. Dr. Musthafa Rajab dalam tulisannya "Ciri-Ciri Masyarakat Israel," mengatakan bahwa masyarakat Israel adalah sekelompok masyarakat yang menyimpan banyak konflik. Mereka adalah keturunan Yahudi yang beranak pinak sangat banyak yang tersebar di seluruh 
pelosok negeri. Karena itu, mereka memiliki ciri kebudayaan yang beragam tergantung dari mana penduduk itu berasal. Perbedaan etnis juga mereka pertahankan, baik antar-Yahudi (bangsa Israel) sendiri atau dengan bangsa selain Yahudi.

Pada akhir 1976, angka Yahudi Timur mencapai $46,2 \%$ dari keseluruhan penduduk Israel di Palestina jika dibandingkan antara generasi eksodus yang saat itu dengan saat sebelumnya. Pemuda Yahudi Timur dengan usia di bawah usia 20 , jumlahnya mencapai 52,4\%. Padahal, eksodus Yahudi Timur ke Palestina menurun sejak tahun 1970, di mana yang berasal dari Uni Soviet paling banyak. Sementara jumlah pemuda Israel Timur mencapai $99 \%$, yang belum menginjak usia 20 tahun dan yang sudah mencapai usia balig jumlah 615.600 , dan mereka dilahirkan di Israel. berikut:

Di antara ciri masyarakat Israel adalah sebagai

(1) Mereka adalah percampuran masyarakat yang sangat beragam dari segi tatanan sosialnya. Artinya, antarindividu Israel mereka tidak sejenis. Karena, mereka adalah percampuran dari akar keturunan, kebudayaan, kecenderungan, tradisi yang berbeda-beda. Karena itu, tujuan sosial mereka sangat beragam.

(2) Mereka adalah masyarakat Yahudi, tapi penduduk negara asli adalah Arab. Ini tatanan sosial yang lebih merumitkan.

(3) Mayoritas Yahudi yang berada di Palestina bukan berasal dari akar yang sama. Mereka berbeda tergantung dari mana mereka berasal atau dari negara asal mereka. Penduduk Arab di sana adalah minoritas yang menetap di kampung halaman mereka, sejak 1948.

(4) Yahudi Israel terdiri dari dua kelompok besar yang jumlahnya hampir sebanding. Namun, status sosial mereka berbeda dalam masyarakat Israel tergantung asal negara dan watak pekerjaan (profesi mereka).

(a) Kelompok pertama: Yahudi Barat atau lebih dikenal dengan "Esykanzim." Mereka eksodus dari negara-negara Eropa atau Amerika. Kebanyakan mereka hidup di kotakota Israel dan negara-negara teluk. Secara kebudayaan dan sosial, mereka dianggap memiliki status sosial tinggi dengan menduduki jabatan dan instansi penting di pemerintah Israel.

(b) Kelompok kedua: Yahudi Timur, yang terkenal dengan "Savardim." Mereka eksodus ke Palestina dari negara-negara Asia dan Afrika. Kebanyakan mereka hidup di kota-kota kecil Israel, wilayah pedesaan. Dalam kehidupan keagamaan dan budaya, mereka berkembang. Di mana mereka melakukan pekerjaan profesi sederhana.

Kelompok terakhir ini tidak memiliki banyak kelebihan keistimewaan dibanding dengan kelompok pertama. Mereka tidak menikmati jabatan penting di pemerintahan melainkan hanya sedikit, terutama di "kursi" Kanneset Israel. ${ }^{13}$

\section{Awal dan Pertumbuhan Yahudi di Palestina}

Jumlah Yahudi kian hari kian bertambah hingga Konferensi Zionis Pertama diadakan di kota Basl, Swiss pada 1897, di mana isu pemukiman dan pertambahan jumlah Yahudi menjadi titik persoalan. Akhirnya semua organisasi yang berpartisipasi dalam konferensi itu, mengupayakan yang terbaik untuk menciptakan suasana baru di Jerusalem guna mendirikan negara Yahudi di Palestina. Sebagai hasilnya, sejumlah penduduk Yahudi sudah mencapai 28,122 sekitar $61.9 \%$ dari populasi kota - 45,430 - tahun 1897.

Setelah itu, janji Balfour, 1917, berperan penting dalam mengizinkan Yahudi untuk berimigrasi ke Palestina secara cuma-cuma. Dan kali ini pun jumlah populasi Yahudi bertambah menjadi 51,200, sekitar 56.6\% populasi kota. Akhirnya, jumlah ini menjadi 99,400 atau sekitar $60.4 \%$ populasi kota $-164,500$ - pada akhir tahun 1947.

Di saat negara Yahudi didirikan pada $15 \mathrm{Mei}$ 1948, areal Jerusalem berjumlah total $21.1 \mathrm{~km} 2,20$ $\mathrm{km} 2$ yang membentuk wilayah Jerusalem baru. Setelah itu, dibagi menjadi wilayah-wilayah berikut sesuai dengan kesepakatan Genjatan Senjata Tahun 1949:

1-Wilayah Arab mencakup 2.4 km2, kira-kira 11.48\% 
wilayah kota.

2- Wilayah yang dijajah Israel mencakup $17.7 \mathrm{~km} 2$, kira-kira $84.03 \%$ wilayah kota.

3- Wilayah yang dikuasai oleh PBB mencakup 1 $\mathrm{km} 2$, kira-kira $4.39 \%$ kota.

Israel tidak saja mendeklarasikan Jerusalem Baru sebagai ibukotanya pada 1948, tetapi ia juga menaneksasi wilayah Jerusalem Timur setelah berhasil menduduki wilayah Tepi Barat dan Jalur Gaza pada 1967. Aneksasi formal dideklarasikan pada 30 Juli 1980. Sejak itu, Israel telah mendeportasikan orang Arab, merampas harta benda mereka, dan membangun sejumlah pemukiman dan koloni Yahudi. Pada sisi lain, Israel juga menghalangi kontak demografis apapun antara kota dan kota-kota Arab atau wilayahwilayah di Tepi Barat, yang pada gilirannya dapat menyedot kedatangan sekitar 170 ribu Yahudi untuk tinggal di pemukiman-pemukiman baru yang sudah disediakan. Diperkirakan sekitara 190 ribu orang Arab yang berada di kota berusaha untuk menentang proses ini, dan sekitara 50 institusi Palestina di kota, seperti Bait al Sharq yang telah dikunjungi oleh sejumlah pejabat Eropa.

Pada umumnya, populasi kota dewasa ini berkisar sekita 700 ribu, $73 \%$ dari semuanya adalah Yahudi. Di sana terdapat banyak sekali rencana Yahudi yang akan dibangun sekitar 153 ribu rumah pada tahun 2010. Hal ini dimaksudkan untuk meningkatkan jumlah populasi menjadi 817 ribu yang mayoritas adalah Yahudi. Dan langkah pertama akan dapat diselesaikan pada tahun 2000.

Pada sisi lain, sejumlah Yahudi di Jerusalem telah tumbuh menjadi $11.1 \%$ dari total jumlah Yahudi di Israel yang diperkirakan sekitar $4,800,000$ pada tahun 1998. Pertarungan demografis yang telah dirancang secara rapih oleh Zionis sejak Konferensi Basl tahun 1897.

Ini merupakan bagian dari pertarungan demografis antara Arab dan Yahudi di seluruh wilayah Palestina guna mencapai supremasi demografis Yahudi atas Arab. Skema zionis ini didasari dengan menarik Yahudi dari kota-kota lain ke Jerusalem dan merampas tanah milik Arab dan harta benda mereka guna membangun kolonikoloni. Skema ini telah rampung sejak Tahun $1997 .{ }^{14}$

\section{Teror Israel: “Zio-Nazism Intergroup Labelling"}

Spirit Nazism tampaknya tumbuh dan berkembang di dalam jiwa kaum Yahudi. Spirit $\mathrm{Na}$ zism ini, yang dikembangkan sebagai karakter Zionis, secara jelas tak pernah bisa memahami moralitas. Yitzhak Shamir pernah berkata, "bukan moralitas Yahudi dan bukan pula tradisi Yahudi bisa digunakan untuk tidak mengijinkan teror sebagai sebuah alat perang...teror adalah sebuah bagian dari pendekatan perang politik untuk ruang lingkup saat ini..."

Begitu banyak bukti menunjukkan bahwa Israel dan Zionism adalah secara aktual merupakan enemi menakutkan bagi bangsa Yahudi itu sendiri maupun bangsa-bangsa lainnya, termasuk Islam dan Kristen, baik di Palestina maupun belahan bumi lainnya. Seperti Nazism, Zionisme adalah sebuah kanker spiritual di dalam kebudayaan dan agama Yahudi, yang mengizinkan negara Israel mengambil alih negara Palestina. Padahal, dalam jangka panjang, kriminal Israel dan persekusi seperti Nazi terhadap bangsa Palestina bisa menjadi bumerang bagi dirinya sendiri. Malangnya, mayoritas Yahudi jauh dari pemahaman yang cukup bahwa tindakan politik dan militer Israel yang genocide dan apartheid itu merusak semangat kemanusiaan universal dan persaudaraan.

Kita bisa mencermati realisasi spirit Zio- $\mathrm{Na}$ zism di dalam segala tindak kejahatan oleh Negara terhadap warga sipil tak berdosa. Maka, apakah salah bila kita mengatakan bahwa Zio-Nazism adalah "State-Terorism" atau Negara Teroris. Perilaku Israel secara terbuka merujuk terhadap kebijakan politik dan militer jahat mereka sebagai "Problem Palestina". Mereka menganggap bahwa bangsa Palestina merupakan penghalang utama di dalam merealisasikan impian-impian mereka untuk membangun imperium Israel Raya yang kuat dan tangguh di wilayah Timur Tengah.

Di satu sisi, bagi Nazi, solusi akhir terhadap bangsa Yahudi adalah "genocide" atau pembasmian etnis Yahudi, di mana bagi Zionism, solusi akhir terhadap "Problem Palestina" bermakna pembantaian dan pembunuhan ribuan orang 
Palestina dan pengusiran semua rakyat Palestina dari negara Palestina. Peristiwa holocaust terhadap 3000 warga sipil Palestina di Sabra dan Satila, Libanon, tahun 1982 dan penghancuran rumah-rumah penduduk, membuktikan spirit $\mathrm{Na}$ zism dalam diri seorang Ariel Sharon.

Bedanya, bila Nazi-Jerman mendapat tentangan keras dari sekutu Eropa dan Amerika pada waktu itu, tapi bangsa Palestina dibiarkan membela dirinya sendiri tanpa dukungan apapun dari dunia Internasional, termasuk PBB yang telah dimandulkan. Bahkan sebaliknya, Zionis Israel justru memperoleh dukungan opini dunia, uang dan persenjataan dari AS maupun Inggris. Kita lihat, di Palestina, tak ada perlindungan untuk rakyat sipil di Tepi Barat maupun Gaza dari berbagai serangan dan pembantaian militer Israel. Bahkan PBB sebagai wakil dari lembaga perdamaian dunia menjadi impoten oleh berbagai veto yang dilancarkan AS.

Setidaknya, ada empat persamaan antara spirit Nazism dan karakter Zionism, yaitu:

Nazi mencita-citakan Negara "Lebensraum", yaitu ruang hidup hanya untuk kaum Nazi, sedangkan Zionis menghayalkan "Erezt Israel" atau Israel Raya, yang membentang dari Sungai Nil sampai ke Sungai Eufrat.

Nazi mengklaim sebagai bangsa Aria, yang merupakan ras tertinggi dan paling baik, sedangkan Yahudi di dalam kitab Talmud-nya mengklaim diri sebagai "Bangsa Pilihan", dan dengan demikian, semua orang non-Yahudi, secara rasial, adalah rendah (inferior).

Orang-orang Nazi merupakan bangsa yang rasis dan jahat, begitu pun kaum Zionis-Yahudi terkenal di dalam sejarah sebagai bangsa yang sangat rasis dan tak bisa hidup berdampingan dengan bangsa-bangsa lain.

Kaum Nazi memandang "problem Yahudi" sebagai penyelesaian akhir, sedangkan Zionis-Israel memandang "problem Palestina" sebagai penyelesaian akhir.

Karena itu sangat disayangkan, di dalam propaganda anti-teroris akhir-akhir ini, tak satu negara pun yang dapat menghentikan terorisme negara Israel, yang bahkan tanpa henti melakukan kejahatan perang tanpa akhir di bumi Palestina, tapi justru mendapat dukungan AS sebagai polisi dunia seperti tampak dalam serangan di bulan Juli, 2002 dan juga Agustus 2003 baru lalu oleh misilmisil perang Israel dari pesawat F-16 yang memborbardir bangunan apartemen di Gaza dan membunuh beberapa orang anak-anak dan penduduk sipil Palestina.

Itu adalah hasil konspirasi antara AS-Israel, sehingga mudah bagi kita untuk menilai bahwa serangan militer Israel ke dalam teritori Suriah sudah memiliki agenda yang jelas, yang diketahui dan didukung oleh pemerintah AS seperti juga serangan angkatan tempur Israel ke wilayah Libanon di atas langit Beirut dan Tripoli. Pengebirian militer Suriah, Libya, dan Iran oleh AS baru-baru ini akan memosisikan Palestina tanpa penopang sedikit pun.

Secara jelas kita semua tahu, tujuan utama dari Zionisme-Israel adalah menempatkan yahudiyahudi imigran ke Palestina dan mengusir penduduk Palestina dari kampung halamannya ke Negara-negara Arab, khususnya Yordania dan Irak Selatan agar terbentuk "Eretz Israel" atau Israel raya, yaitu tanah yang dijanjikan di dalam Talmud, meliputi Saudi Arabia, Suriah, Yordania, Mesir sampai ke Irak, atau wilayah yang sekarang membentang dari sungai Nil sampai sungai Eufrat. Untuk merealisasikan mimpi Israel Raya itulah, kaum Zionis terus berusaha untuk mengusir rakyat Palestina di wilayah Yerusalem Timur, Tepi Barat dan Gaza agar keluar dari Palestina menuju Gurun Sinai dan Yordan.

Namun, ada yang membuat galau Israel. Tumbuh dan berkembangnya gerakan Intifadhah kedua, 28 September 2000, yang telah memasuki tahun ketiga ini, ternyata dapat mengguncangkan basis-basis pertahanan Israel oleh berbagai aksi syahid rakyat Palestina. Bom syahid merupakan reaksi keras dari berbagai individu Muslim bangsa Palestina untuk mengusir penjajah Zionis-Israel. Di sisi lain, protes-protes intifadhah tersebut semakin meningkatkan kampanye dan propaganda Yahudi untuk meneror penduduk Palestina melalui pengusiran, penghancuran rumah-rumah penduduk, penangkapan para aktivis sampai 
pembunuhan wanita dan anak-anak Palestina. Korban terbesar seringkali terjadi di Gaza dan kamp pengungsi Jenin di Tepi Barat. Selain itu, Israel juga terus berupaya melanjutkan program pembangunan "Tembok Berlin-"nya dan perluasan pemukiman baru Yahudi di wilayah Palestina.

Jelaslah bahwa gerakan Zio-Nazisme selalu ditopang oleh "terorisme negara Israel dan AS" untuk melanjutkan proses penjajahan di bumi yang makin transparan dan global ini. Kaum Zio-Nazism tak akan pernah bisa memahami dan mengenal keadilan dan kemanusiaan kecuali bahasa kekuasaan dan kekuatan. ${ }^{15}$

\section{Perlawanan Tanpa Senjata}

Siapapun memahami bahwa setiap bangsa mempunyai hak-hak dasar untuk mempertahankan diri. Bangsa Palestina, tentu saja, mempunyai suatu hak moral untuk mempertahankan diri mereka sendiri melawan serangan dan intimidasi Israel. Tapi Israel tak juga bisa memahami bahwa ia seharusnya mampu hidup berdampingan dengan bangsabangsa lainnya, termasuk Palestina. ${ }^{16}$

Perlawanan dilakukan, namun yang terjadi setelah bertahun-tahun dilakukan tetap tidak berhasil. Karena ketidakseimbangan persenjataan, di mana rakyat Palestina tidak punya senjata yang mereka gunakan adalah batu dan ketapel melawan senjata berat tank, rudal dan lain-lain. Dan akhirnya mereka melakukan bom Syahid yang dikatakan oleh media adalah bom Bunuh Diri.

Menurut Dr. Abdul Aziz Ranteesi yang mendorong putra-putra Palestina antri mempersembahkan dirinya sebagai bom manusia. Dengan begitu, barangkali, mereka dapat mengatasinya - dan saya tidak yakin mereka mampu melakukan itu - agar senjata utama dan menggetarkan ini lepas dari para pemuda muslim. Pertama, mempertahankan diri dari apa yang dipentaskan Israel yang didukung oleh Amerika dan Inggris, berupa pembantaian terencana dan dengan darah dingin terhadap putra-puteri umat Islam yang terisolasi di Palestina. Dengan sewenang-wenang mereka menyerang dan membantai anak-anak, pemuda, orangtua, dan wanita di ladang pembantaian massal maupun secara sendiri-sendiri. Selang kurang lebih satu abad, tak satu pun rumah warga Palestina yang selamat dari bencana yang menyakitkan ini. Pembantaian telah meninggalkan ribuan jandajanda dan puluhan ribu anak yatim. Bagaimana mungkin orang-orang Palestina dapat menjaga darah anak-anak mereka, kalau tidak ditebus dengan harga kejahatan musuhnya.

Kedua, mempertahankan tanah air. Perampasan tanah Palestina dan pengusiran rakyatnya telah dipentaskan rezim imperialis Israel sejak 1948, dengan kekuatan senjata, juga penggelandangan jutaan warga Palestina yang meneguk kehinaan dan pelarangan di kamp-kamp pengungsi. Sementara, para durjana Yahudi mendirikan negara mereka di atas puing-puing rakyat Palestina, di atas gundukan jasad anak-anak Palestina. Negara yang dibangun di atas darah, air mata, dan rintihan bocah-bocah dan wanita Palestina. Bagaimana mungkin kami membebaskan tanah air kami dan mengembalikan anak-anak kami ke kota-kota dan desa-desa mereka, juga menghadapi permusuhan para durjana itu, jika kami harus menanggalkan senjata yang mampu menghilangkan rasa aman dan eksistesi musuh kami.

Ketiga, mempertahankan tempat-tempat suci. Bagaimana caranya membersihkan tempattempat suci umat Islam, khususnya Masjidil Aqsha dari Yahudi, bagaimana meramaikan masjid-masjid Palestina yang telah menjadi peninggalan para pendahulu setelah dihancurkan oleh Yahudi, bahkan telah mereka ubah menjadi tempat-tempat kemaksiatan.

Keempat, untuk membebaskan para tawanan. Imperialis Israel masih terus melakukan penangkapan secara luas terhadap warga Palestina yang terisolasi. Lebih dari sepuluh ribu warga Palestina dalam tahanan, mereka mendapatkan perlakukan sangat buruk dan tidak manusiawi di sebuah penjara yang di sebut Penjara Anshar di padang pasir Nagev. Bagaimana mungkin mereka dapat menghirup kebebasan kalau tidak dibayar oleh Imperialis Israel dengan harga kesewenang-wenangan mereka. 
Kelima, membela hak-hak politik dan sipil. Harus ada perlawanan menghadapi tekanan mihwar setan dan kejahatan terhadap Pemerintah Otoritas Palestina dan negara-negara Arab untuk memburu para pemuda Islam, menekan, menangkap dan rencana upaya pembunuhan terhadap mereka. Di samping itu juga pelarangan terhadap organisasi-organisasi Islam mengaktualisasikan hak-hak sipil dan politiknya, melarang ikut serta dalam menentukan nasibnya. Mereka di kepung, diisolasi dan segala aktivitas yang berkenaan dengan kemaslahatan tanah airnya ditentang. Mereka dituduh dan ditempatkan dalam daftar teroris, diusunglah agresi informasi zalim yang penuh dengan kebohongan untuk memojokan mereka.

Keenam, membela hak rakyat Palestina hidup terhormat. Hal itu hanya dapat dilakukan dengan melakukan perlawanan terhadap politik pengepungan (blokade), penghancuran dan pelaparan yang dilakukan oleh Zionie Israel yang didukung oleh mihwar setan dan kejahatan. Tujuannya, menundukan dan menghinakan rakyat bangsa Palestina, menutup lembaga-lembaga sosial yang memberikan bantuan kepada korban teroris Zionis Yahudi, mengharamkan bagi pemuda Palestina untuk menikmati kesempatan hidup terhormat di bawah naungan negara yang didirikan di atas tanah historis mereka.

Ketujuh, mempertahankan kekayaan nasional. Harus ada perlawanan terhadap apa yang dilakukan oleh mihwar setan dan kejahatan menyedot hasil kekayaan milik kaum Muslimin, yang menjadikan jutaan umat Islam mati kelaparan. Sementara, itu Barat bersama-sama dengan orang-orang Yahudi berfoya-foya menikmati harta kekayaan yang dikuras dari Palestina. Mereka menguasainya untuk memukul rakyat Palestina dan menyebarkan kerusakan di tanah air dan negara Palestina. ${ }^{17}$

\section{Penutup}

Perbedaan ideologi, pandangan hidup, dan agama ternyata sangat mempengaruhi komuniksi yang terjadi. Dengan adanya perbedaan yang mengarah kepada konflik mengakibatkan komunikasi semakin sempit. Karena komunikasi yang terjadi terjadi dalam bentuk bentrokan fisik di antara kedua pihak. Jadi, komunikasi tersebut berjalan dengan konflik dan peperangan itu sendiri. Kemudian dengan adanya konflik ini, timbullah labelling antara kedua fihak yang bertikai. Setiap fihak mempunyai labelling dari pihak yang lain. Seperti, Palestina menganggap Israel Penjajah, Zio Nazism, sementara pihak Israel menganggap orang Palestina sebagai teroris, fundamentalis, dll.

Solusi terhadap konflik yang terjadi, adalah adanya pihak-pihak struktural yang menjadi mediator terhadap konflik ini dan kemudian memberikan jalan dengan memberikan hak-hak yang telah diambil oleh mereka-mereka yang mengambil tanah orang lain tanpa izin

\section{Catatan Akhir}

Harian Pikiran Rakyat, Senin, 19 April 2004, hlm. 1

2 Dikutif dari buku Deddy Mulyana, Ilmu Komunikasi, Suatu Pengantar, pada halaman 41-42, yang membahas hakikat, Definisi, dan Konteks Komunikasi.

3 Onong Uchjana Effendy, bercerita tentang perkembangan dari pada ilmu Komunikasi, pada halaman 3-4.

4 Terdapat pada tulisan Deddy Mulyana, yang berjudul Menjadi Manusia Antarbudaya, pada halaman 234235. Tulisan ini terdapat pada buku Komunikasi Antarbudaya, yang merupakan kumpulan tulisan.

5 Lihat buku Media-Meliter-Politik. Crisis Communication: Perspektif Indonesia dan Internasional. Tulisan Deddy Mulyana, yang berjudul "Intergroup Labelling di Indonesia," halaman 69-70.

6 Lihat halaman 128-129 Buku Media Militer dan Politk. Crisis Communication: Perspektif Indonesia dan Internasional. Editor Lukas Strategi Isfandriarno, Thomas Hanitzsch dan Martin Loeffelholz. Pada tulisan Lambang Trijono yang berjudul "Peran Komunikasi dalam Konflik dan Untuk Perdamaian"

7 Ibid halaman 130

8 ibid halaman 135

9 Hal ini terdapat di dalam buku Human Communication, pada Bab III Komunikasi kelompok Kecil, pada 
sub bab Tingkat konflik, halaman 100. Secara gamblang diuraikan mengenai tingkat konflik yang terjadi. Sementara pendapat Smith dan Berg terdapat di halaman 98 .

10 Dikituf dari buku Human Communication. PrinsipPrinsip Dasar, pada sub Bab "Pendekatan Terhadap Konflik”, pada halaman 221.

11 Terdapat pada buku Lathief Rousydiy yaitu DasarDasar Rhetorica Komunikasi dan Informasi, yaitu pada halaman 98 yang berbicara mengenai "rintanganrintangan dalam berkomunikasi."

12 Baca tulisan dari A. Jafar M Sidik yang berjudul "Kekacauan Global dan Sentimen Anti Yahudi"Harian Pikiran Rakyat, 5 Januari 2004. (Rujukan utama dari Artikel Antiglobalism's Jewish Problem dalam jurnal Foreign Policy, edisi November/December 2003)

13 Diambil dari harian Al Syarq Al Qothoriah, edisi 2 Juli 2003 dalam "Kolom Analisa Pusat Informasi Palestina", yang diakses 15 April 2004.

14 Baca tulisan Nabil Al Sahli yang berjudul "Jerussalem", Kolom Analisa Pusat Informasi, tertanggal 28 Desember 2003, 5:40:21 PM. Diakses 15 April 2004.

15 Tulisan Muhammad Safari yang berjudul "Zio Nazism." Kolom Analisa Pusat Informasi Palestina, tertanggal 1 Desember 2004. Diakses 15 April 2004. Tulisan ini juga terdapat di COMES: Center for Middle East Studies.

16 Ibid, pada pendahuluan

17 Ranteesi, Aziz, Abdul. "Mengapa Pemuda Palestina Berlomba-Lomba Melakukan Bom Syahid." Kolom Analisa Pusat Informasi Palestina, tertanggal 5 September 2003. Diakses 15 April 2004

\section{Daftar Pustaka}

Mulyana, Deddy. Ilmu Komunikasi Suatu Pengantar.Bandung: Rosdakarya, 2000.

Mulyana. Deddy, dan JalaluddinRakhmat, (ed). Komunikasi Antarbudaya. Panduan Komunikasi dengan Orang-Orang Berbudaya. Bandung: Rosdakarya, 1996.

Ranteesi, Abdul Aziz. "Mengapa Pemuda Palestina Berlomba-Lomba Melakukan Bom Syahid." Kolom Analisa Pusat Informasi Palestina, tertanggal 5 September 2003.
Diakses 15 April 2004 from: http:// www.infopalestina.com/viewall.asp? $\mathrm{id}=289$

Ispandriarno, S, Lukas dkk(ed). Media-MiliterPolitik. Crisis Communication: Perspektif Indonesia dan Internasional. Yogyakarta:Friedrich Ubert Stiftung dan Galang Press Yogyakarta, 2002.

Tubbs. L. Stewart dan Moss Sylvia. Human Communication. Konteks-Konteks Komunikasi. Buku Kedua. Bandung: Rosdakarya, 2001.

Tubbs. L. Stewart dan Moss Sylvia. Human Communication. Prinsip-Prinsip Dasar Buku Pertama. Bandung: Rosdakarya, 1996.

Rousydiy, Lathief, T, A. Dasar-Dasar Rhetorica Komunikasi dan Informasi. Medan: Rimbow, 1989.

Sidik, M, Jafar, "Kekacauan Global dan Sentimen Anti Yahudi." Bandung: Artikel Harian Pikiran Rakyat, 5 Januari 2004.

Effendy, Uchjana, Onong. Ilmu Komunikasi Teori dan Praktek. Bandung, Remaja Rosdakarya, 1997.

Rajab, Musthafa, "Ciri-Ciri Masyarakat Israel." Kolom Analisa Pusat Informasi Palestina, tertanggal 28 Desember 2003, diakses 15 April 04, http://www.infopalestina.com/ viewall.asp?id=467 9/28/2003 12:16:36 PM.

Sahli, Al, Nabil, "Jerussalem,” Kolom Analisa Pusat Informasi Palestina, tertanggal 28 Desember 2003, 5:40:21 PM. Diakses 15 April 2004. from: http://www.infopalestina.com/ viewall.asp?id $=2003$

Safari, Muhammad, "Zio Nazism.” Kolom Analisa Pusat Informasi Palestina, tertanggal 1 Desember 2004. Diakses 15 April 2004 from:http://www.infopalestina.com/ viewall.asp?id=138533:13 PM

Harian Pikiran Rakyat, 19 April 2004, berjudul Pemimpin Baru Hamas Diroket Israel. 